\title{
Improving relations between business strategy and marketing tactics
}

\author{
Hrvoje Medarac* \\ European Commission - Joint Research Centre, \\ Institute for Energy and Transport, \\ Renewables and Energy Efficiency Unit - TP 450, \\ Via E. Fermi, 2749, I-21027 Ispra (VA), Italy \\ Email: Hrvoje.Medarac@ec.europa.eu \\ *Corresponding author
}

\section{Gianpaolo Vignali}

School of Materials, University of Manchester, Oxford Rd, Manchester, M13 9PL, UK

Email: gianpaolo.vignali@manchester.ac.uk

\section{Claudio Vignali}

The University of Vitez,

Školska 23, 72270 Travnik,

Bosnia and Herzegovina

Email: claudiov@btinternet.com

\begin{abstract}
The purpose of this research was to develop a new strategic marketing model which would help to improve the relations between business strategy and marketing tactics. The chosen research methodology was phenomenology and the combination of action research and case study was recognised as the most appropriate research method. The main findings of the research were that there was the gap for logical upgrading of the existing marketing models which would make them simple and interactive and that the new developed Stratics model improves the business result of the company. The main practical implication of this research is the developed Stratics 2.0 model which is as a piece of academic knowledge available for free download and use. The originality of this research lays in the developed Stratics model which contributed to the overall knowledge in the field of business strategy and marketing tactics. This research was performed as a part of $\mathrm{PhD}$ thesis.
\end{abstract}

Keywords: ICT business strategy; marketing tactics; matrix marketing; life cycle; BCG matrix; Ansoff matrix; GE/McKinsey matrix; marketing mix; Mixmap; Stratics.

Reference to this paper should be made as follows: Medarac, H., Vignali, G. and Vignali, C. (2016) 'Improving relations between business strategy and marketing tactics', Int. J. Business and Globalisation, Vol. 16, No. 1, pp.50-65. 
Biographical notes: Hrvoje Medarac is a Scientific/Technical Project Officer at European Commission-Joint Research Centre, Institute for Energy and Transport. His educational profile is a combination of mechanical engineering in energy field and economics specialised in management and marketing. He gained professional experience in public and private sectors, mostly in the field of energy and particularly in renewables and energy efficiency. He worked for the Croatian Ministry of Economy, The Environmental Protection and Energy Efficiency Fund and in companies Lega and Enerkon. His research activities in EC-JRC are related to renewable energy markets. His professional experience in economics comes from managing the company Lega.

Gianpaolo Vignali is a graduate from UMIST with his first degree in Mathematics. Later adding a Master's in Strategic Management, his career first started as a part-time Lecturer and researcher at Manchester Metropolitan University before moving to full-time employment in the Department of Retail at Leeds Metropolitan University. He then became the Program Leader for Fashion Buying and Merchandising at Manchester Metropolitan University until he achieved his $\mathrm{PhD}$ and moved to Manchester University working in the School of Materials where he delivers on both undergraduate and postgraduate programs. He has written over 40 papers and books in the field of marketing and management and presented at numerous international conferences. His current research focuses on the case study technique in the service sector which coincided with his PhD program of study.

Claudio Vignali held The Arnold Ziff Chair in Retail Marketing Management and is the Head of CIRCLE. He joined Leeds Metropolitan University from the Manchester Metropolitan University. He holds Chairs in Croatia; Poland; Italy and Germany and delivers MBA and DBA modules for leading UK universities. He wrote more than 150 articles and books and is the Editor of two academic journals. He worked for Crown Berger Paints and Benetton. Currently, he is the head of postgraduate distance learning courses at Vitez. He helped in the development of the professional diploma in sales. He supervises $\mathrm{PhD}$ students Europe-wide.

This paper is a revised and expanded version of a paper entitled 'The stratics model-strengthening the link between business strategy and marketing tactics-research application' presented at 11th International CIRCLE Conference, University of Manchester, 23-26 April 2014.

\section{Introduction}

In theory, the marketing tactics should be in line with business strategy, but in many companies practitioners saw that this was not the case. The main source of this problem comes from the fact that business strategy is supposed to be prepared by top management and marketing tactics by middle level management responsible only for marketing.

The strategy has been the focus of understanding the level of competitiveness and strength for a long time during the history and both in ancient Europe where the term strategy comes from comes from Greek words strategoi, strategos, stratos and agein which would mean 'the art of leading the army' (Buble et al., 2005) and in ancient Asia where Sun Tzu (republished in 2002) discussed on possibilities to gain stronger position and defeat the enemy. There are many authors who write about strategy or at least 
provide the definition of it like Porter (1980), Thompson et al. (2005), Vignali et al. (2010) or Buble et al. (2005).

As an important part of each business, the marketing would be an organisational function of the company which has the purpose to make customers more interested in products. Like in the case of strategy, the marketing is also a widely used term which was examined by many authors like Kotler (2001), Stralser (2004), Buble et al. (2005), Cooper and Schindler (2006), Kennedy (1989), Mlivić Budeš (2008) or Vranešević et al. (2006).

\section{Approach}

The aim of this research was to develop a live model for coordination of marketing tactics with business strategy (Medarac, 2014). The Mixmap model developed by Vignali and Davies (1994) combined the product life cycle (PLC), Boston Consulting Group Matrix (BCGM) and Ansoff Matrix as strategic tools, with the marketing mix as a tactical tool in order to improve the relationship between business strategy and marketing tactics. This model was used as the basis of the development of the Stratics model.

The research had two objectives (Medarac, 2014):

- to find out more about marketing strategy and tactics models which have already been developed

- to develop a live Stratics model and test its applicability on a specific company.

Based on these objectives, two research questions were made (Medarac, 2014):

1 Is there a gap for logical upgrading of the existing marketing models which can keep them simple and interactive?

2 Does the developed marketing model improve the business result of the company?

With taking into consideration various aspects of positivistic and phenomenological approach discussed by authors such as Buttery and Buttery (1991), Bonet and Sauquet (2010), French (2009), Nørreklit et al. (2010) or Yin (1994), the research methodology which was recognised in this research as the most appropriate to reach the aim and objectives was the phenomenology.

In order to answer the first research question, a secondary data analysis was made during the literature review process, while for the purpose of answering the second research question, the analysis of the primary data was chosen and the action research in the combination with the case study was identified as the most appropriate research method.

\section{Scientific innovation and relevance}

The main contribution to knowledge of this research was the Stratics model, a marketing strategy model which extended the knowledge of relations between the main strategic and tactical tools and improved the usage of matrix marketing approach in the decision making process. The Stratics 2.0 model is as a piece of academic knowledge, generally available to wide users at the web page http://www.lega.hr/en/stratics.php. 
Although the model is the contribution by itself, it has also main piles of contribution.

1 Interactiveness - Stratics model is an interactive tool which enables what-if analyses which were previously not possible in the case of the Mixmap model developed by Vignali and Davies (1994).

2 Weight factors - introduction of importancy levels of variables as weight factors enabled more realistic and more precise calculation of the real position of the company and more precise conclusions on the impact of a certain variable on the position of the company. The introduction of Likert-scale improved the quality and precision of answers.

3 Calculation of real position in GE/McKinsey matrix - the calculation of real position of the company improved the idea of Mixmap model in a way that now there was the possibility to understand which is the real position of the company. Previously, in the Mixmap model the real position was not calculated, but assumed based on expert analysis of seven different matrices and the conclusions were made by comparing the matrices among each other. The presentation of the final result in GE/McKinsey matrix provided the user with more clear picture on what does the real position of the company actually mean in terms of future needed strategic actions.

4 Artificial intelligence - the introduction of artificial intelligence methods enabled the users to easily understand the basic result of the Stratics model in terms of suggested strategic and tactical moves without entering into deeper, more expert analyses.

5 Extended marketing mix - the initial Mixmap model used 4P marketing mix, but the authors suggested the possibility to use the extended marketing mix instead. Stratics model followed this suggestion and included the extended marketing mix in process which enabled wider applicability and higher level of precision of the model.

\section{Research details}

The research process began in 2005 when the researcher had the opportunity to see the Mixmap model and decided to improve it. The Stratics model was developed in cycles during the period from 2006 to 2012 and in the scope of the action research process, the model was tested on several companies in each cycle and deeply implemented in the company Lega d.o.o.

\subsection{Literature review}

Main fields of the literature review covered existing marketing models which help to improve business strategy and marketing tactics and its relations, and model building.

The literature review gave positive answer to the first research question and identified the gaps based on which the Stratics model was supposed to be developed in the scope of the research:

- the model should be interactive

- the model should calculate the resulting position of the company according to proposed business strategy and marketing tactics of the company 
- there is the need to introduce importancy levels as the weighting factors for all variables in order to increase the precision of the model

- artificial intelligence methods should be implemented in order to allow the Stratics model to suggest the measures which should be taken to reach business strategy goals through an appropriate application of marketing tactics

- if necessary, the GE/McKinsey matrix should be included in the process.

\subsection{Primary research}

Primary research was conducted as the action research on a case study for Croatian company Lega. The researcher chose Croatian company as he had a had good understanding of Croatian business economy and the company Lega was chosen for the action research as the researcher had the power to make decisions in this company and to implement the Stratics model during the research process. For this reason, the research showed the applicability of the Stratics model on Croatian market, but since the model itself was based on grounded theory which is the same worldwide, the expectation was that he model should also be applicable on other markets too. In order to check the applicability of the model on other markets, the model was tested in additional 27 companies during the action research process. The combination of action research and case study was chosen as selected research strategy as the Stratics model is an interactive model which was developed and implemented in phases and there was the possibility to control the implementation during the research process.

\subsubsection{Primary research description}

Cooper and Schindler (2006, p.65) define a proposition as "a statement about observable phenomena (concepts) that may be judged as true or false. When a proposition is formulated for empirical testing, we call it a hypothesis. As a declarative statement, a hypothesis is of a tentative and conjectural nature". Main proposition of this action research was the following:

P Does the developed marketing model improve the business result of the company?

The research was examined by the usage of the business analysis of the company before (control sample) and after (test sample) each of the phases of the action research process. The researcher had the access to company's historical data and started the business analysis process of a control sample from 2006, before the Stratics model was implemented in the company. Main part of data analysis was based on the balance sheet and the income statement, while the other data was collected directly from company's management which ensured the reliability of the data. The research control was ensured since the researcher had the decision making rights. In this way, there was no other internal influence on business result except the influence of the model. 
The company chosen to be the case in the action research process on the case study was a small Croatian enterprise Lega d.o.o. from Zagreb where the researcher already had the access to confidential data on strategy and market and had the influence in making business decisions at all levels.

It is also important that within the testing phase of the action research process, the Stratics model has been tested in 27 companies of various size and industries which proved that the model had wider applicability. The users of the Stratics model during the testing phase were managers of companies which took part in the action research and MBA students. In the cases of some MBA students, they already had the knowledge of main strategic management and marketing models and used the Stratics model independently after which the in-depth interviews and observing were used as research methods in order to reach the input data for further future steps of the action research and development of the Stratics model. In other cases, when MBA students did not use the model by themselves and also in the cases of managers which were not a part of the group of MBA students, the researcher was leading the process of usage of the Stratics model and making analysis. In these cases, the researcher reached the research data on testing the model in various industries already during the process of model usage and in these cases the methods used to collect the data were in-depth interviews and focus groups. Main reason for testing the model on 27 companies was the examination of the applicability of the model on various industries, various markets and in the companies with various sizes. These companies came from the following industries: marketing products, energy engineering, banking, consultancy, telecommunications, pharmacy, tourism, food, sports, courier services, general engineering, investment, railway products and human resources. Some of them competed on local market, some on Croatian national market, some on regional market and some of them were present globally. The size ranged from just a couple of employees or even no employees to more than 50,000 employees.

Main research limitation in this action research was that in the case of a strong external influence like the recession which started in Croatia in 2009 and was still present in 2013, there was a strong influence of the negative impact of the recession on market conditions. In that case, the business result was compared to the other market players and global situation on the market.

\subsubsection{Primary research analysis}

The company Lega, which took part in the research, is a small size enterprise which produces mathematical models and provides energy consultancy services, where the market of mathematical models is considered as the main market of the company which is explained in more details by Medarac (2012).

The action research process started in 2007 and it was conducted in the similar way as suggested by Kock (2004) which is shown in Figure 1 (Medarac, 2014).

The first step was the development of the model which included steps 'diagnosis' and 'action planning' from the general action research process suggested by Kock (2004). In this phase, the model was redeveloped based on findings from previous steps of the action research process. 
Figure 1 Action research process in the development of Stratics model (ibid.) (see online version for colours)
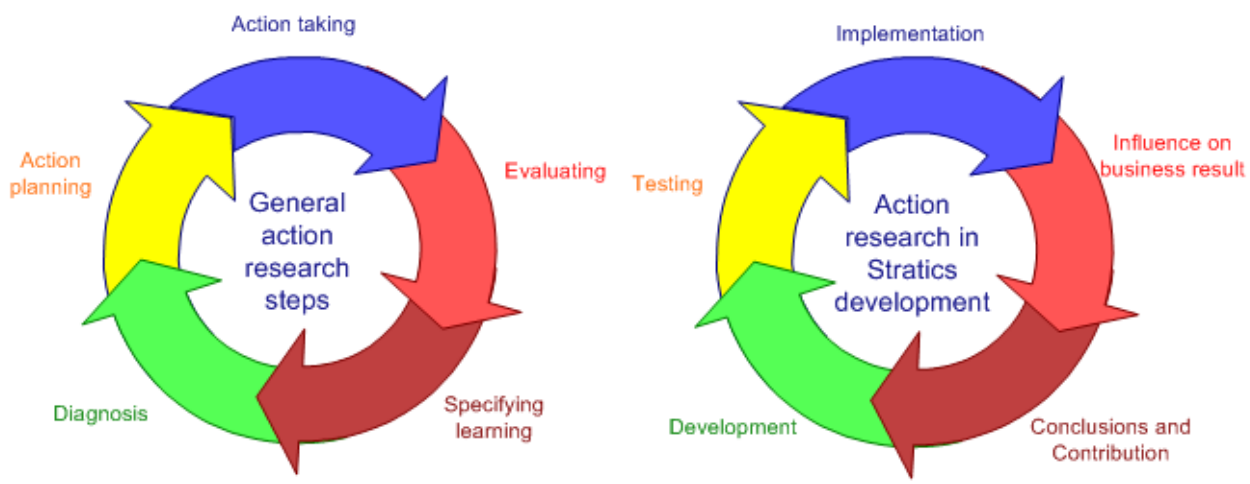

The second step was testing phase where the purpose was to see how independent users use the model and to find out if there was the need to redevelop the model according to the feedback.

The third step was implementation, which refers to the 'action taking' step of the general action research process. In this step, the model was implemented in strategy of the company Lega in each year during the action research process.

The fourth step was the 'evaluation' step from the general action research process which is called the influence on business result. In this step, the company's business result is evaluated with business analysis tools using data from company's annual financial reports but also the internal company's data on marketing.

The fifth step delivered conclusions on each of the cycles of the action research process. In the general action research process, this is the step of 'specifying learning'.

In this research, the additional step which was made was the contribution of the model to knowledge. This step was introduced since the research was a part of the process of preparing the $\mathrm{PhD}$ thesis and in general action research process this is also a part of the step of specifying learning.

\subsubsection{Cycles of the action research}

Regarding the initial conditions in 2006, a business analysis of the company Lega was made for a period of previous several years to get the information on business result, market conditions and market approach before the implementation of the Stratics model. In the period before 2005, the company focused on old clients and starting from 2005 the focus was also moved towards new clients. In order to approach new clients, the emphasis was given to presentations for potential customers, but still the number of offers was higher than the number of presentations until 2006, which witnessed a passive approach to new markets. Total net value of offers decreased significantly in 2005 and 2006 as also decreased the average value of offers and contracts. The decrease of total assets was visible since 2004 and since 2005 the total income was at the lowest level since 2001. This all brought to the first experience of loss since the establishment of the company in 1994. 


\subsubsection{Cycle 1-Stratics 1.0}

The first cycle of the action research process started in 2007. The Stratics model 1.0 was developed on the basis of the Mixmap model on the platform of MS Excel 2003 with MS Visual Basic support on a single-sheet interface. As the addition to the Mixmap model, the Stratics model was interactive and introduced the weight factors of the variables which were used in the Mixmap model and the calculation of the real position of the company.

Stratics 1.0 was tested on six companies and deeply implemented in the company Lega during the period of crisis on the market caused by problems with the company's main customer. As a consequence of the usage of the model Stratics 1.0, a new, long-term contract was signed with one new customer to keep the company operational until it recovered from significant changes on the market. In 2007, the company ended up with an improved business result which brought to the conclusion that the model Stratics 1.0 had a positive impact on the business result of the company Lega d.o.o.

\subsubsection{Cycle 2-Stratics 1.1}

The second cycle of the action research process started in 2008. The Stratics model 1.1 was developed as the improvement of the Stratics model 1.0 since during the testing phase the phenomenon was seen that the users considered it as limited and not enough user-friendly. In order to solve this issue, the Stratics 1.1 was developed in the form of a survey and the option 'other' was added so that now the user could choose the variable which he finds the most appropriate.

The model Stratics 1.1 was tested and implemented together with the Stratics 1.2 as they were developed in the short period of time in 2008.

\subsubsection{Cycle 3-Stratics 1.2}

The third cycle of the action research process was also made in 2008. The Stratics model 1.2 was developed since the observing of the analysis process in Stratics 1.0 and Stratics 1.1 models showed that it was possible to introduce the artificial intelligence methods in the analysis of the resulting diagrams.

Stratics 1.1 and 1.2 were tested on five companies and implemented in the company Lega during the global financial crisis which had a significant influence on Lega's market since companies started reduction of investments which is evident from the research performed by Medarac $(2009$, p.85) who proved rebalancing of marketing budgets in Croatian food industry: "Food Companies in Croatia decrease budgets for marketing activities in the period of global financial crisis and recession in Croatia". But still, the business result of the company Lega was better in 2008 than in the year before which showed that the Stratics 1.2 model had a positive impact on the business result of the company Lega d.o.o.

\subsubsection{Cycle 4-Stratics 1.3}

The fourth cycle of the action research process started in 2009. The Stratics model 1.3 was developed as the improvement of the Stratics 1.2 model since there was the need to adapt the model to MS Vista and MS Office 2007 platform and it was noticed that in the 
artificial intelligence part of the Stratics 1.2 model it was not evident how important the suggestions of the model were. This issue was solved in a way that the information on importance levels of variables was now evident also in the interface of the artificial intelligence module.

Stratics 1.3 was tested on seven companies and implemented in the company Lega during a period of crisis caused by the start of recession in Croatia. Although the marketing activities, as suggested by the model, enabled much better visibility on the market and significantly higher number of potential customers recognised the products of the company Lega which is visible through the increase of both the number and the value of offers, the contracting level did not follow as expected. The buying power of customers caused by recession was so low that the company ended up with the greatest loss of all time and in the same time the long-term contract from 2007 ended also as a consequence of buyer's lack of purchasing power in the middle of 2009. This situation of market closing was similar for all market players which all suffered from vast decrease of income as discussed by Medarac (2012). In the end, one cannot say that developed model Stratics 1.3 improved the business result of the company Lega, but it showed to be a strong tool to prepare the company in taking defensive position on the market at a time of severe financial crisis, resulting positively on overall business results.

\subsubsection{Cycle 5- Stratics 1.4}

The fifth cycle of the action research process started in 2010. The Stratics model 1.4 was developed as the major improvement of the Stratics model based on findings from the literature review. In this model, the usage of GE/McKinsey matrix was implemented in the resulting diagram and the analysis of the result by artificial intelligence methods was also included.

Stratics 1.4 was tested and implemented together with the Stratics 1.5 as they were developed in the short period of time in 2010.

\subsubsection{Cycle 6-Stratics 1.5}

The sixth cycle of the action research process was also made in 2010. The Stratics model 1.5 was developed since the analysis of testing and implementation of previous instances showed that the scale from 0 to 10 in the form of slide was not appropriate enough for weighting factors which represent the importance value of variables as in many cases, users were setting all importance levels to the highest values (between 5 and 10) and almost none of these values were low (ibid.). In order to solve this problem, the literature review was performed which identified the Likert-scale with seven options as the appropriate one.

Stratics 1.4 and 1.5 were tested on six companies and implemented in the company Lega during the recession period in Croatia. In 2010, the company once again made loss in demanding market conditions, but although the company made loss, the model Stratics 1.5 had a positive impact on the business result of the company Lega since it helped to improve the position when comparing to 2009 and helped in defending the position and decreasing the influence of recession. 


\subsubsection{Cycle 7 - Stratics 2.0}

The seventh and final cycle of the action research process was performed in 2011. The Stratics model 2.0 was developed based on findings from testing and implementation of previous versions of Stratics model that $4 \mathrm{P}$ marketing mix did not provide enough of flexibility for all industries. In order to solve this issue, the extended marketing mix has been introduced as Vignali and Davies (1994) suggested and the values of variables were given flexible boundaries.

Stratics 2.0 was tested on three companies and implemented in the company Lega during the recession period in Croatia. In 2011, the company once again made loss in demanding market conditions, but although the company made loss, the model Stratics 2.0 had a positive impact on the business result of the company Lega since it helped to improve the position when comparing to 2010 and helped in defending the position and decreasing the influence of recession.

\subsubsection{Primary research conclusions}

During the action research process, the research was undertaken on the main proposition P:

Does the developed marketing model improve the business result of the company?

Primary research was undertaken on the company which faced problems on the market before the usage of the Stratics model. The only year when the company Lega operated in normal business environment was 2007, the first year of implementation of the model, while in 2008 the company competed in the conditions of global financial crisis which started closing the market and since 2009 the company continuously operated in conditions of recession in Croatia which according to Eurostat databases (Official web pages of Eurostat, 2014) still lasted in 2013.

With taking into account these heavy market conditions, the model showed to be valuable both in conditions when there is the need to improve the business result in usual situation and when there is the need to make decisions on defensive actions in periods of strong negative external influence.

For this reason, the answer to the proposition $\mathrm{P}$ of the primary research was the following:

Yes, the developed marketing model improves the business result of the company.

\section{Results - the Stratics model}

The main result of the research is the Stratics model, which was developed on the foundations of the Mixmap model (Vignali and Vignali, 2009). The Stratics model uses basic strategic and tactical tools to connect the strategy and tactics as it is presented in Figure 2 (Medarac, 2014). This figure shows that in order to begin usage of the Stratics model, first the situational analysis has to be done and some of tools which are used in this approach are business analysis, analysis of competitors, market research, Porter's five forces model, SWOT and value chain analysis. 
Figure 2 Stratics model flow chart (ibid.) (see online version for colours)

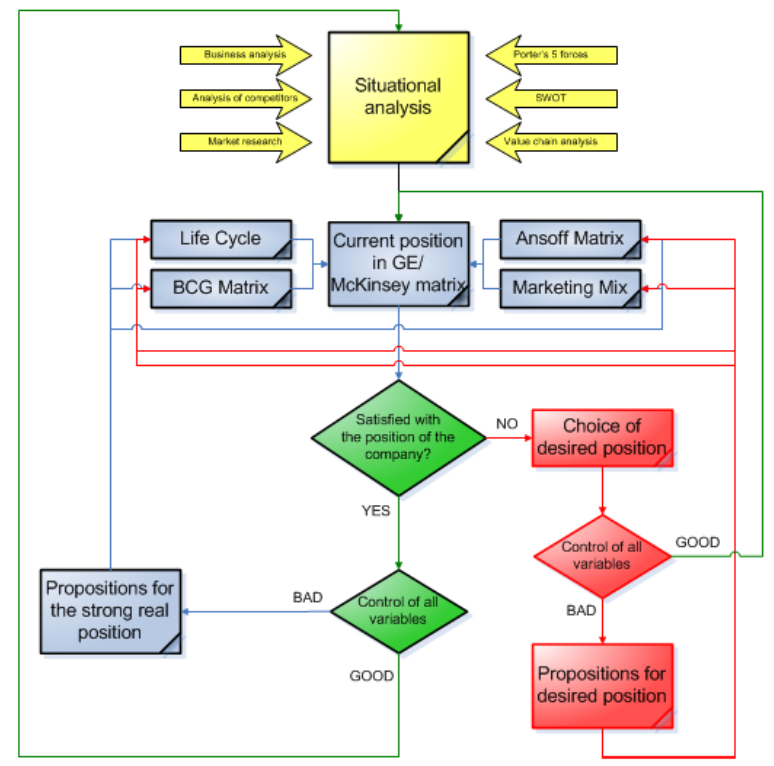

Situational analysis helps in preparing the input data for life cycle, BCG matrix, Ansoff matrix and marketing mix which the Stratics model uses to calculate the position of the company in GE/McKinsey matrix. The Stratics model is not a typical decision support system aimed to provide decision support for a certain and unique customer, but a general simulation mathematical model aimed to provide support in strategic marketing process.

The following figures show how the Stratics model is used in real conditions. The first couple of pages are meant to describe current strategic position of the company. Figure 3 shows the life cycle page.

Figure 3 Stratics 2.0 - life cycle (ibid.) (see online version for colours)

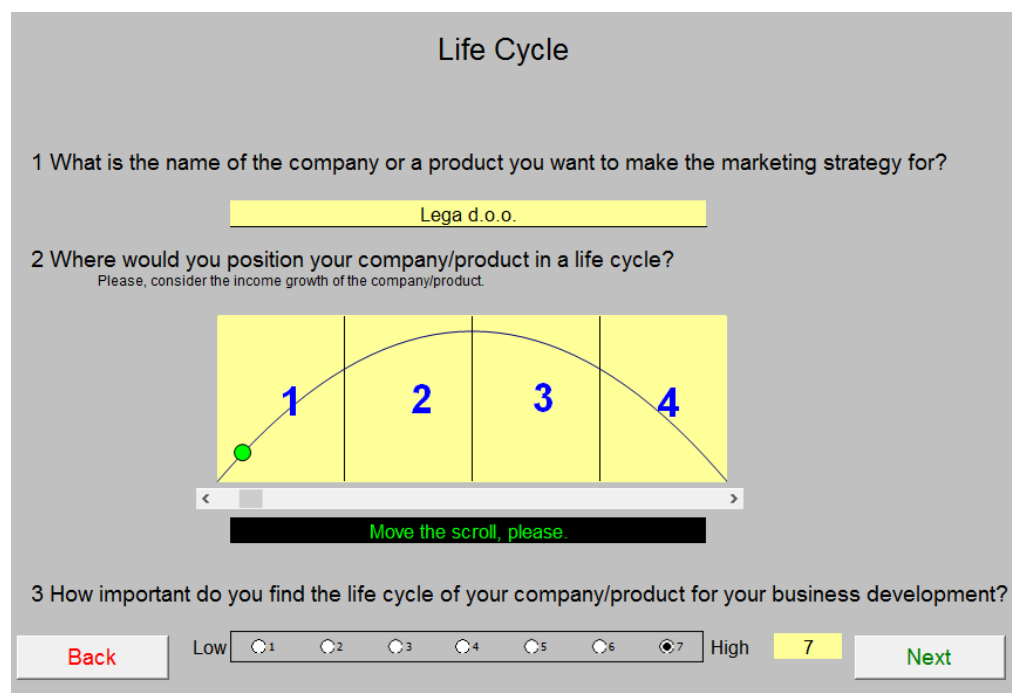


The second page represents the position of the company in Boston Consulting Group Matrix as shown in Figure 4.

Figure 4 Stratics 2.0 - BCG matrix (ibid.) (see online version for colours)

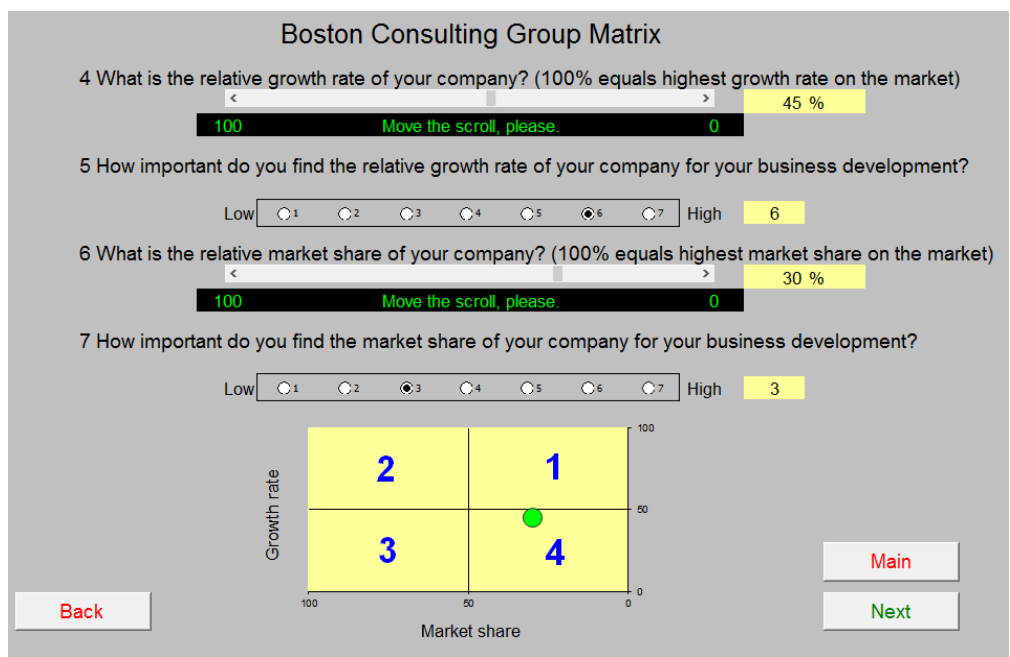

The third page represents the position of the company in Ansoff matrix as shown in Figure 5 .

Figure 5 Stratics 2.0 - Ansoff matrix (ibid.) (see online version for colours)

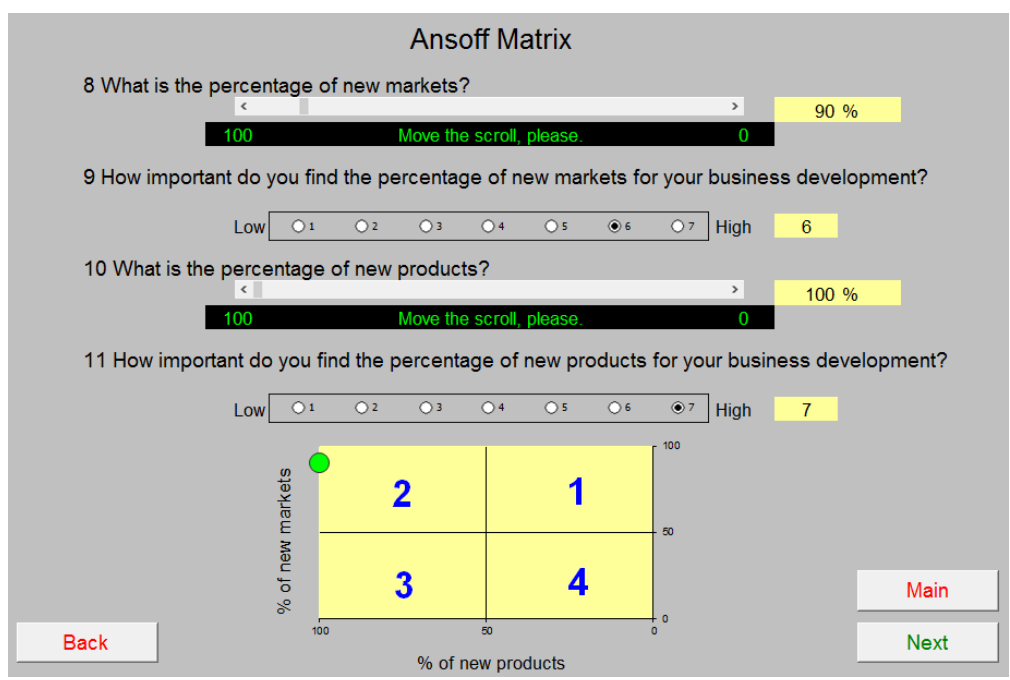

After the strategy has been defined, there is the need to define the marketing tactics for which the extended marketing mix is used. Figure 6 shows the main interface where the elements of marketing mix and main variables are chosen. 
Figure 6 Stratics 2.0 - marketing mix elements and variables (ibid.) (see online version for colours)

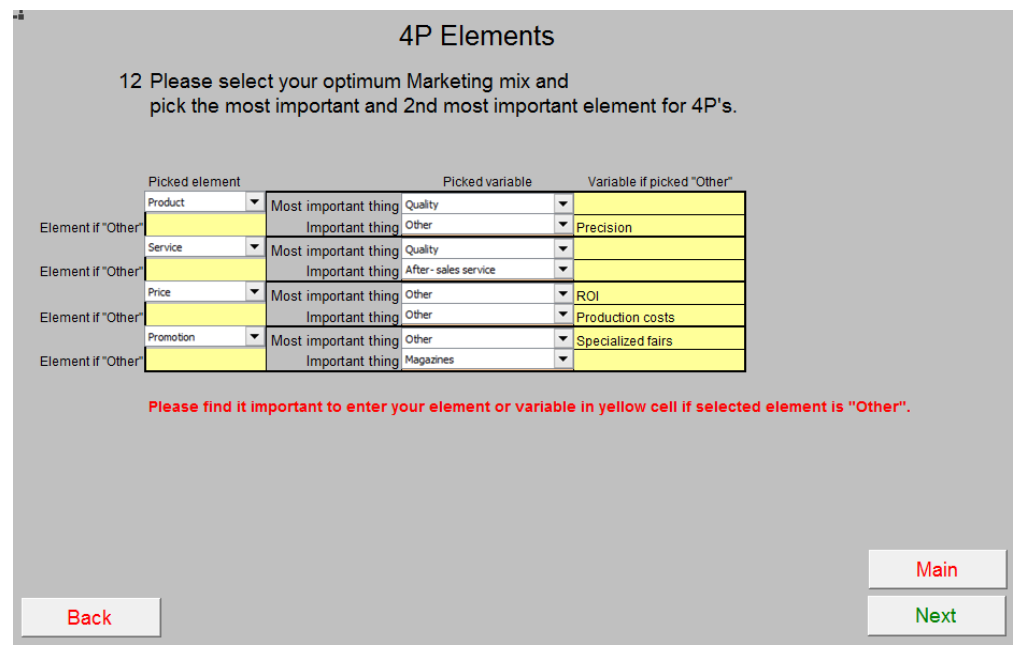

When the main elements and variables of marketing mix are chosen, the data is entered in each of marketing mix matrices as shown in Figure 7.

Figure 7 Stratics 2.0 - typical marketing mix element (ibid.) (see online version for colours)

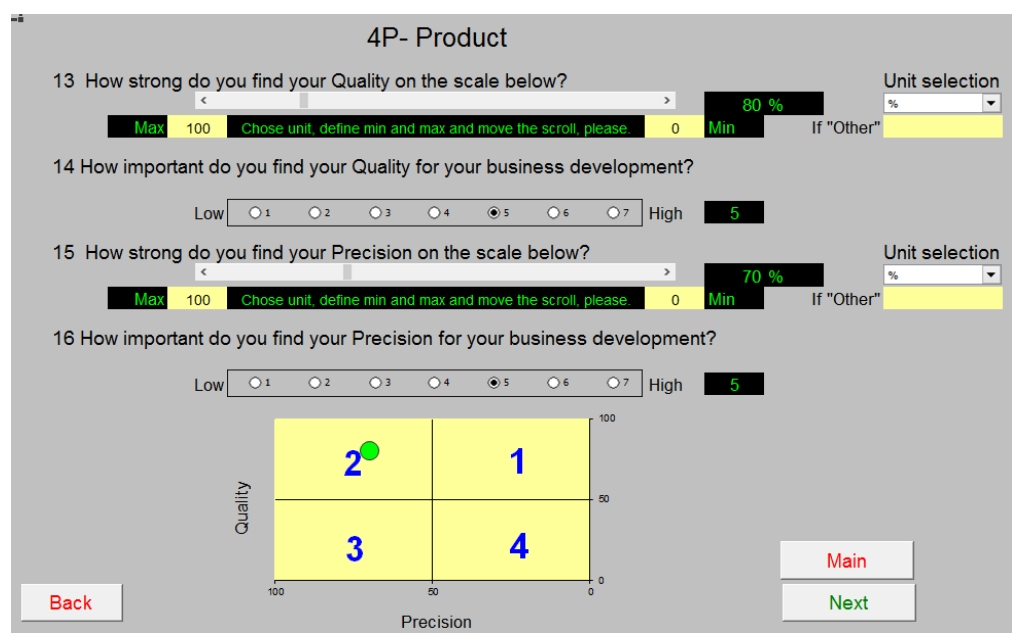

Final result is presented in the main interface of Stratics 2.0 model as shown in Figure 8 where the resulting position of the company is presented in GE/McKinsey matrix and sliders next to matrices allow for making what-if analyses. 
Figure 8 Stratics 2.0 - main interface of Stratics 2.0 (ibid.) (see online version for colours)

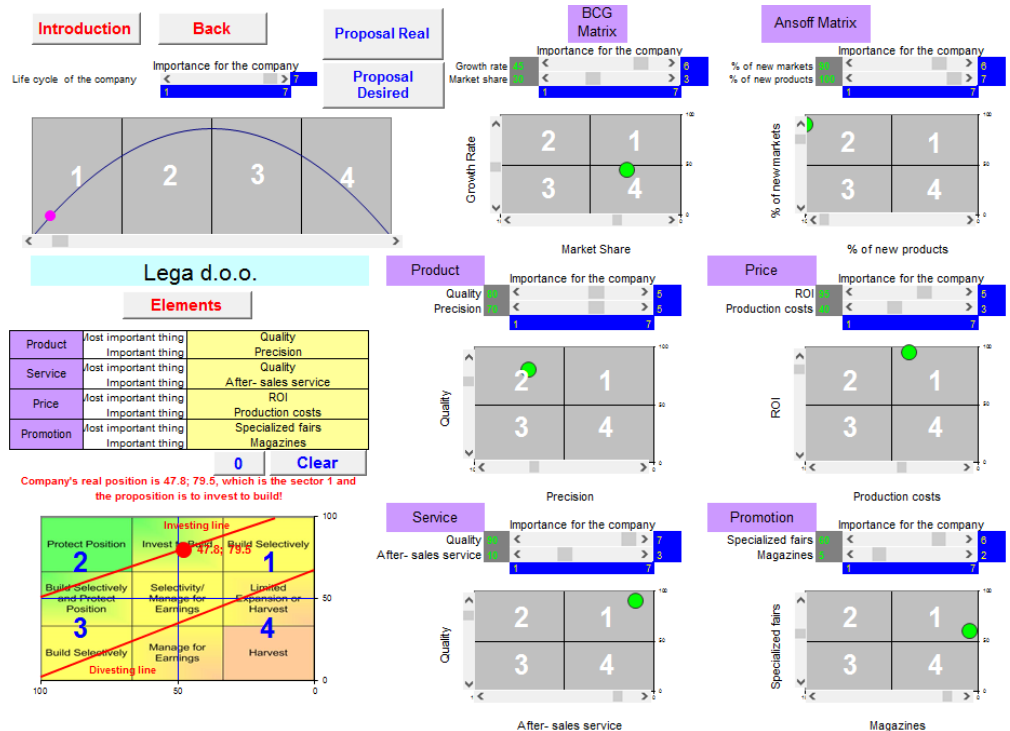

In the end, the model provides suggestions for reaching the strong real position of the company or desired position of the company as shown in Figure 9.

Figure 9 Stratics 2.0 - interface of the artificial intelligence module (ibid.) (see online version for colours)

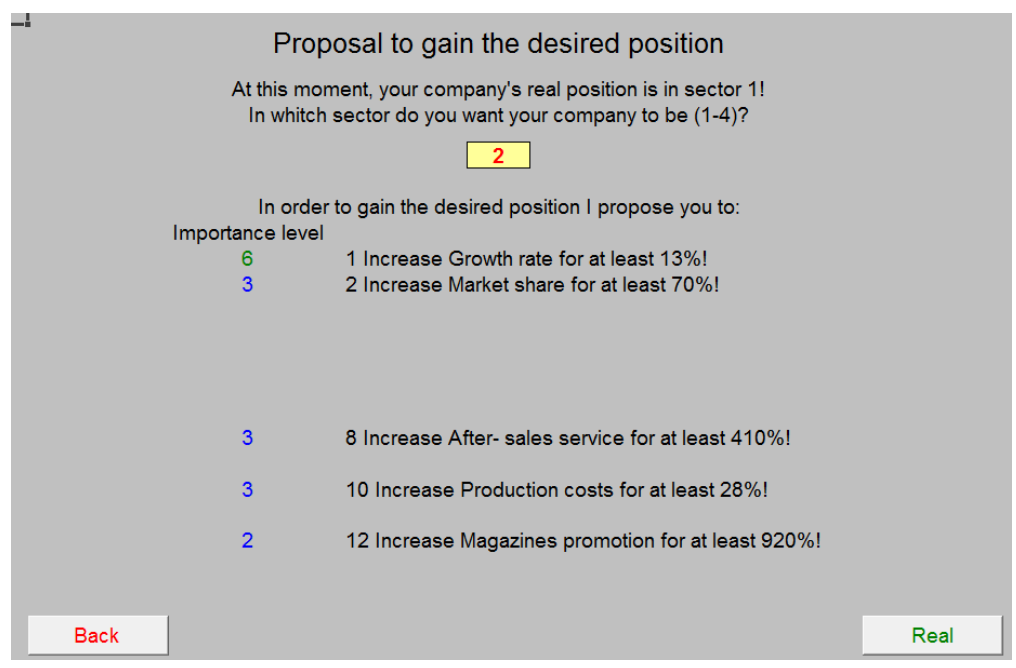

The model, as the piece of academic knowledge is available for free download on the following link: http://www.lega.hr/en/stratics.php. 


\section{Conclusions}

The developed Stratics model can be considered as a very valuable model which helps to improve relations between business strategy and marketing tactics (Vignali, 2014). The main aim of the research was to develop the model and to test it in real-life conditions.

The first part of the research process showed that there was a gap for the logical upgrading of the existing marketing models by making them more simple and interactive. On the basis of this conclusion, the action research process was undertaken on the case study of the company Lega and the Stratics model was developed.

The second part of research showed that the developed marketing model indeed improved the business result of the company

Although the action research was made on the case of one small enterprise, the testing of the model on 27 companies proved that the model can also be applied to companies of various size, from various industries and not only in Croatian market conditions.

\section{References}

Bonet, E. and Sauquet, A. (2010) 'Rhetoric in management and in management research', Journal of Organizational Change Management, Vol. 23, No. 2, pp.120-133.

Buble, M., Cingula, M., Dujanić, M., Dulčić, Ž., Gonan Božac, M., Galetić, L., Ljubić, F., Pfeifer, S. and Tiputić, D. (2005) Strateški Menadžment (Strategic management), Sinergija, Zagreb, Croatia.

Buttery, E.A. and Buttery, E.M. (1991) 'Design of a marketing information system: useful paradigms', European Journal of Marketing, Vol. 25, No. 1, pp.26-39.

Cooper, D.R. and Schindler, P.S. (2006) Marketing Research, McGraw-Hill, USA.

Eurostat (2014) [online] http://epp.eurostat.ec.europa.eu/portal/page/portal/statistics/ search_database (accessed 22 April 2014).

French, S. (2009) 'Cogito ergo sum: exploring epistemological options for strategic management', Journal of Management Development, Vol. 28, No. 1, pp.18-37.

Kennedy, D.S. (1989) 63 'Killer' Marketing Strategies - How To Insure That Your Product/Service/Offer Is The Best It Can Be, Presented The Best Way It Can Be, Kimble and Kennedy Publishing, Austin, USA.

Kock, N. (2004) 'The three threats of action research: a discussion of methodological antidotes in the context of an information systems study', Decision Support Systems, Vol. 37, pp.265-286, Elsevier B.V.

Kotler, P. (2001) Marketing Management, Millenium ed., Pearson Custom Publishing, Boston, USA.

Medarac, H. (2012) Strategic Analysis of the Market of the Business Optimisation Software in Energy and Process Industries in Croatia, Master's thesis, University of Zagreb, Zagreb, Croatia.

Medarac, H. (2014) Matrix Marketing and Technology Innovation-The Development of Strategic Marketing Model Building, PhD thesis, Leeds Metropolitan University, Leeds, UK.

Medarac, K. (2009) Position of Marketing in Croatian Food Industry in a Period of Global Financial Crisis, Master's thesis, University of Gloucestershire, Cheltenham, UK.

Mlivić Budeš, E. (2008) Marketinški vodič (Marketing Guide), Filaks d.o.o., Zagreb, Croatia.

Nørreklit, H., Nørreklit, L. and Mitchell, F. (2010) 'Towards a paradigmatic foundation for accounting practice', Accounting, Auditing \& Accountability Journal, Vol. 23, No. 6, pp.733-758.

Porter, M.E. (1980) Competitive Strategy, Free Press, New York, USA. 
Stralser, S. (2004) MBA in A Day - What You Would Learn at Top-Tier Business Schools (If You Only Had the Time!), John Wiley \& Sons, Inc., New Jersey, USA.

Sun Tzu (republished in 2002) The Art of War, Penguin Books, London, UK

Thompson Jr., A.A., Stricklan, III, A.J. and Gamble, J.E. (2005) Crafting and Executing Strategy: The Quest for the Competitive Advantage: Concepts and Cases, 14/e, McGraw-Hill/Irvin, USA.

Vignali, C. and Davies, B.D. (1994) 'The marketing mix redefined and mapped: introducing the MIXMAP model', Management Decision, Vol. 32, No. 8, pp.11-16, MCB University Press Limited, UK.

Vignali, C. and Vignali, G. (2009) 'The mix map method', Fashion Marketing and Theory, Vol. 79, No. 92, pp.79-92, Access Press UK in Association with GSE Research.

Vignali, G. (2014) 'The mix map modelling approach: research application - a thought for the service industry', International Journal of Business and Globalisation, Vol. 12, No. 1, pp.75-81.

Vignali, G., Vignali, C. and Ryding, D. (2010) The Strategy Process, Access Press UK, Darwen, UK.

Vranešević, T., Vignali, C. and Vrontis, D. (2006) Marketing and Retailing Strategy, Accent, Zagreb, Croatia.

Yin, R.K. (1994) 'Discovering the future of the case study method in evaluation research', American Journal of Evaluation, Vol. 15, No. 3, pp.283-290. 